\title{
Transforming growth factor- $\alpha$ in vivo stimulates epithelial cell proliferation in digestive tissues of suckling rats
}

\author{
K Hormi, T Lehy
}

\begin{abstract}
Background-The role that exogenous transforming growth factor- $\alpha$ (TGF- $\alpha$ ) may exert on cell proliferation in vivo is poorly understood.

Aim-To investigate the effect of rat TGF- $\alpha$ on epithelial cell proliferation in all suckling rat digestive tissues and to compare it with that of rat epidermal growth factor (EGF).

Animals and Methods-TGF- $\alpha$ and EGF were given three times daily either subcutaneously (10 or $20 \mu \mathrm{g} / \mathrm{kg}$ ) or intraperitoneally $(100 \mu \mathrm{g} / \mathrm{kg})$ to rats from the ninth postnatal day. Cell proliferation was assessed through 5-bromo- 2-deoxyuridine incorporation and estimation of labelling indices.

Results-For both growth factors, the highest dose given for only two days significantly increased stomach and intestinal weights compared with controls $(p<0.05$ to $p<0.001)$. The proliferative responses depended on the dose given, colonic mucosa being the most sensitive whereas oxyntic mucosa remained unresponsive. TGF- $\alpha$ was as potent as EGF in stimulating epithelial cell proliferation in antral, duodenal, and colonic mucosae. However, EGF was more active on oesophageal and jejunal cell proliferation whereas TGF- $\alpha$ was more active on pancreatic exocrine cell proliferation and the differences between the two growth factor treated groups were significant.

Conclusions-These results prove for the first time the stimulating effect in vivo of exogenous rat TGF- $\alpha$ on epithelial cell proliferation in rat digestive tissues during the developmental period and support a functional role for $\mathrm{TGF}-\alpha$ at that time.

(Gut 1996; 39: 532-538)
\end{abstract}

Keywords: rat EGF, rat TGF- $\alpha$, labelling indices, organ weight.

Transforming growth factor- $\alpha$ (TGF- $\alpha$ ) and epidermal growth factor (EGF) are mitogenic peptides of 50 and 53 amino acids respectively, which share many structural homologies. They have a similar range of biological activities mediated through the same receptor, EGF-r, a $170 \mathrm{kDa}$ transmembrane glycoprotein with an intracellular tyrosine kinase domain. In the gastrointestinal tract,
TGF- $\alpha$ was reported to inhibit gastric acid secretion and promote healing of gastric ulcers in a similar fashion to EGF. ${ }^{1-7} \mathrm{TGF}-\alpha$ is also assumed to act primarily as an autocrine growth factor promoting, for instance, the growth of human digestive adenomas and cancer cell lines. ${ }^{8-11}$ Furthermore, it has been shown to stimulate the proliferation of normal gastric epithelial cells in vitro in dogs and guinea pigs. ${ }^{12-14}$ However, a response in vitro is not necessarily reproduced in vivo, and the effect of exogenous TGF- $\alpha$ on epithelial cell proliferation in normal digestive tissues in vivo is essentially unknown. A preliminary report in adult parenterally fed rats mentioned that TGF- $\alpha$, when given systemically, is a less potent mitogen than EGF on gastrointestinal tissues. ${ }^{15}$ Overexpression of TGF- $\alpha$ in transgenic mice promotes proliferation of acinar cells in the pancreas and of progenitor cells in the stomach, the second being associated with hypertrophy of gastric mucosa and overproduction of mucus. ${ }^{16-18}$ The effects of EGF on gastrointestinal cell proliferation found in adult animals in vivo are controversial, often depending on the route of administration as well as the animals' condition-fed or fasted. ${ }^{19-21}$ In newborn rodents, however, EGF given either by oral, subcutaneous, or intrapetitoneal routes, is able to exert trophic effects in some digestive tissues. ${ }^{22-26}$

Recent studies in our laboratory have shown the developmental expression of TGF- $\alpha$ in the digestive system of rats and humans. ${ }^{27} 28$ In rats, specific binding sites for EGF were found in the small intestine of full term fetuses but the temporal appearance of $\mathrm{TGF}-\alpha$ was more precocious than that of EFG. ${ }^{29-31}$ These data suggest that TGF- $\alpha$ rather than EGF is the true ligand for EGF-r during the developmental period in that animal.

These facts prompted us to check whether TGF- $\alpha$ is an active stimulating factor on epithelial cell proliferation in all digestive tissues of suckling rats. In addition, the TGF- $\alpha$ effect was compared with that of EGF on the same tissues to determine if the two peptides differed in their potency to evoke tissue proliferative responses in developing animals. The end point was incorporation of 5-bromo2-deoxyuridine (5-BrdU), a non-isotopic thymidine analogue (Sigma Chemical Co, St Louis, MO, USA). We used rat EGF and rat TGF- $\alpha$ so that experiments were conducted under physiological conditions. 


\section{Methods}

\section{ANIMALS}

Pregnant Wistar rats weighing 320 (SEM 17) $\mathrm{g}$, were received in our animal quarters on the 14th day of gestation. They were housed in individual cages, kept in temperature $\left(21 \pm 1^{\circ} \mathrm{C}\right)$ and humidity controlled room, and given standard rat food pellets and water ad libitum. The rats were carefully checked for time of birth and the day of birth was referred as day 0 . On the second day after birth, pups were weighed and the litters restricted to 10-11 pups according to the dam's body weight. At the beginning of each experiment, each litter was divided into two or three subgroups of equal average body weights. Pups were marked for group identification. They were allowed to suckle for the duration of the experiment and their body weights were recorded daily. All experiments were carried out in accordance with National Institutes of Health (NIH) guidelines.

\section{EXPERIMENTAL GROUPS}

In a pilot study, two groups of five and six pups received subcutaneous (sc) injections of either rat TGF- $\alpha$ (molecular weight 5617, purity $>98 \%$ by high performance liquid chromatography (HPLC)); (ICN Biochemical Inc, Aurora, Ohio, USA) diluted in $0.9 \% \mathrm{NaCl}$ at a dose of $10 \mu \mathrm{g} / \mathrm{kg}$, or $0.9 \% \mathrm{NaCl}$ (controls). Injections were performed three times a day at $700 \mathrm{am}$, and $300 \mathrm{pm}$, and $1100 \mathrm{pm}$ for five days. Treament began on postnatal day 9 at $300 \mathrm{pm}$. Rats were killed on day 14 between 200 and $400 \mathrm{pm}$-that is, seven to nine hours after the last injection.

In a second experiment, three litters were used. Each litter was divided into three subgroups which were treated in the same way and during the same period as in the pilot study. Rats (10 for each group) received either rat TGF- $\alpha$ or rat EGF (molecular weight 5377, purity $>95 \%$ by HPLC; Biomedical Technology Inc, Stoughton, MA, USA) diluted in distilled water, or $0.9 \% \mathrm{NaCl}$. For both peptides, the dose was $20 \mu \mathrm{g} / \mathrm{kg}$. Rats were killed seven to nine hours after the last injection.

In a third experiment, two litters were also divided into three subgroups. In that series, rats (seven per group) were given intraperitoneal (ip) injections of either rat TGF- $\alpha$ or EGF at a dose of $100 \mu \mathrm{g} / \mathrm{kg}$ body weight, or $0.9 \% \mathrm{NaCl}$, three times daily for two days beginning on day 9 at $300 \mathrm{pm}$. They were killed on postnatal day 11 between 500 and $700 \mathrm{pm}$-that is, 10-12 hours after the last injection.

To investigate the proliferative activity of epithelial cells, all rats received an ip injection $(50 \mathrm{mg} / \mathrm{kg})$ of $5-\mathrm{BrdU} 45$ minutes before killing.

At the time of killing, rats were anaesthetised with ether and the digestive organs were removed. Stomachs were opened along the greater curvature, gently rinsed in $0.9 \% \mathrm{NaCl}$, and blotted dry. Faeces were expelled from the colon by delicate massage. Pancreases were totally removed and carefully trimmed free of fat and lymph nodes. Stomachs, pancreases, and intestines (small and large bowel) were then weighed.

HISTOLOGICAL PROCEDURES AND ASSESSMENT OF CELL PROLIFERATION

Stomachs were pinned flat on a paraffin wax block, mucosal side up, and fixed in a freshly prepared cold Carnoy's solution for 30 minutes. After fixation, stomachs were dehydrated and parallel strips were resected perpendicular to the cardiapylorus axis, embedded in paraplast, and cut into $3 \mu \mathrm{m}$ thick sections strictly perpendicular to the mucosal surface. The pancreas, samples of the lower oesophagus, and $2-3 \mathrm{~cm}$ of the proximal duodenum, jejunum (excised in mid-length of small intestine), and descending colon were histologically processed in the same manner.

Proliferating epithelial cells were identified by immunohistochemistry with an antiBrdU monoclonal antibody (Monosan, Am Uden, Netherlands) used in a $1 / 10$ dilution, and the Vectastain ABC kit (Vector Labs, Burlingame, USA). Immunocomplexes were visualised with diaminobenzidine. Labelled cells were recognisable under the microscope by the brown pigment overlying their nuclei. Tissue sections were then counterstained with Mayer's glychemalun-eosin and examined at $1000 \times$ magnification for pancreas and fundic mucosa and $500 \times$ magnification for all other tissues. This was done on coded slides, examiners being unaware of their origin. Proliferative variables were assessed in the following ways.

For the oesophagus, labelled and unlabelled cells in the basal germinal epithelial layer were recorded in two different cross sections, examining $900-1200$ cells per rat.

For antral, duodenal, jejunal, and colonic mucosae, 30 well oriented glands with the lumen visible from the bottom to the mucosal surface and with a single layer of cells along the column of the gland were selected in longitudinal tissue sections as previously described. ${ }^{32}$ In each column, the total number of cells (starting from the middle of the base up to the surface) and the number of labelled cells were recorded. Totals of about 850-1000 cells per region per rat were counted.

For fundic mucosa, as individual glands are rarely cut along their entire length, labelled and unlabelled epithelial nucleated cells were counted, using a calibrated ocular grid, in eight to nine rectangular fields covering the proliferative zone. This was done at regular intervals from the lesser to the greater curvature, along the length of one well oriented section of oxyntic mucosa. In the developing rat, proliferating cells are widely distributed within the thickness of the oxyntic mucosa and the proliferative zone was defined as the mucosal portion between the highest labelled cells and the lowest, roughly located near the muscularis mucosae. ${ }^{26} 3233$ As parietal cells do not proliferate, these cells, recognisable by their shape and their eosinophilic cytoplasm, 
were excluded from the counts. At least 1000 cells were examined per rat.

For the exocrine pancreas, 10 different tissue areas were selected at random using an ocular grid, and about 1000 acinar cells per rat were examined. Centroacinar cells, which have their own proliferation rate, were excluded from counts.

Labelling indices-the percentage of labelled cells in the proliferative area for each tissuewere then estimated.

\section{STATISTICAL ANALYSIS}

All results are expressed as means (SEM). Statistical comparisons for independent populations between all groups were made with one way analysis of variance (ANOVA) or the nonparametric Kruskall-Wallis test whenever relevant. When significant overall effects were found, comparisons between two groups were made with Student's $t$ test or the MannWhitney $U$ test. The level of significance was set at $\mathrm{p}<0.05$.

\section{Results}

ANIMAL AND DIGESTIVE ORGAN WEIGHTS

In all experiments, mean body weight curves were similar for controls and treated pups, so that at the end of the experimental period, animal weights were similar. Weights of digestive organs did not differ between controls and treated pups in the first two experimental series (data not shown). In the third experiment, administration of TGF- $\alpha$ or EGF $(100 \mu \mathrm{g} / \mathrm{kg} /$ day) for only two days resulted in a significant increase in intestinal weights compared with the control group, whether the data were expressed as absolute weight or wet weight $/ 100 \mathrm{~g}$ body weight $(11.2$ to $19.5 \%$, with $\mathrm{p}<0.005$; Table I). Stomach weights were also significantly increased in the EGF treated group compared with the control group $(p<0 \cdot 05)$. For the TGF- $\alpha$ treated group, the difference compared with controls was significant only for absolute weight, $p<0.05$ ( $p<0.10$ for wet weight $/ 100 \mathrm{~g}$ body wt). Absolute

TABLE I Effect of two day intraperitoneal administration of rat TGF- $\alpha$ or rat EGF on weights of digestive organs in suckling rats

\begin{tabular}{|c|c|c|c|}
\hline & $\begin{array}{l}\text { Controls } \\
(n=7)\end{array}$ & $\begin{array}{l}E G F \\
(n=7)\end{array}$ & $\begin{array}{l}T G F-\alpha \\
(n=7)\end{array}$ \\
\hline \multicolumn{4}{|l|}{ Absolute weight: } \\
\hline $\begin{array}{l}\text { Beginning of experiment } \\
\text { End of experiment }\end{array}$ & $\begin{array}{l}21.4(0.4) \\
26.9(0.5)\end{array}$ & $\begin{array}{l}21 \cdot 6(0 \cdot 6) \\
26 \cdot 3(0 \cdot 7)\end{array}$ & $\begin{array}{l}21.9(0 \cdot 6) \\
27 \cdot 3(0 \cdot 5)\end{array}$ \\
\hline Pancreas (mg) & $86 \cdot 6(3 \cdot 6)$ & $\begin{array}{l}100 \cdot 6(4 \cdot 9)^{\star} \\
(+16 \cdot 2 \%)\end{array}$ & $77 \cdot 9(13 \cdot 0)$ \\
\hline Stomach (mg) & $179 \cdot 0(5 \cdot 0)$ & $\begin{array}{l}208 \cdot 0(8 \cdot 1)^{\star \star} \\
(+16 \cdot 2 \%)\end{array}$ & $\begin{array}{l}209 \cdot 4(12 \cdot 2)^{\star} \\
(+17 \%)\end{array}$ \\
\hline Intestine (mg) & $893 \cdot 0(10)$ & $\begin{array}{l}1017 \cdot 0(25)^{\star \star \star} \\
(+13.9 \%)\end{array}$ & $\begin{array}{l}1008 \cdot 0(14)^{\star \star \star} \\
(+12 \cdot 9 \%)\end{array}$ \\
\hline $\begin{array}{l}\text { Wet weight }(\mathrm{mg} / 100 \mathrm{~g} \text { body we } \\
\text { Pancreas }\end{array}$ & $322 \cdot 5(14 \cdot 6)$ & $\begin{array}{l}384 \cdot 9(25 \cdot 0) \\
(+19 \cdot 3 \%)\end{array}$ & $332 \cdot 4(19 \cdot 6)$ \\
\hline Stomach & $666 \cdot 8(22 \cdot 6)$ & $\begin{array}{l}796 \cdot 3(48 \cdot 3)^{\star} \\
(+19 \cdot 4 \%)\end{array}$ & $\begin{array}{l}768 \cdot 4(48 \cdot 1) \\
(+15 \cdot 2 \%)\end{array}$ \\
\hline Intestine & $3327 \cdot 0(72)$ & $\begin{array}{l}3869 \cdot 0(84)^{\star \star \star \star} \\
(+16 \cdot 3 \%)\end{array}$ & $\begin{array}{l}3699 \cdot 0(74)^{\star \star \star} \\
(+11 \cdot 2 \%)\end{array}$ \\
\hline
\end{tabular}

Values are means (SEM). The doses of rat EGF and TGF- $\alpha$ were $100 \mu \mathrm{g} / \mathrm{kg}$ three times daily. Increased percentages are given in parentheses. ${ }^{\star} p<0.05 ;{ }^{\star \star} \mathrm{p}=0.01 ;{ }^{\star \star \star} \mathrm{p}<0.005 ;{ }^{\star \star \star \star} \mathrm{p}<0.001$ pancreatic weight alone was significantly increased in the EGF treated group compared with controls, $(p<0 \cdot 05$; Table I).

DNA SYNTHESIS INDICES IN EPITHELIAL PROGENITOR CELLS OF DIGESTIVE TISSUES In the pilot experiment, we tested a low dose of rat TGF- $\alpha,(10 \mu \mathrm{g} / \mathrm{kg})$. In a previous study, a similar dose of mouse EGF had been able to stimulate cell proliferation in the pancreas and small intestine of the suckling rat. ${ }^{26}$ This dose, given subcutaneously, was studied here on selected organs-namely, the oesophagus, pancreas, jejunum, and colon. Figure 1 shows labelling indices estimated in these tissues. Compared with controls, TGF- $\alpha$ stimulated epithelial cell proliferation only in the colonic mucosa, $(27 \%, \mathrm{p}<0.01)$

In the second experiment, taking into account the above results, the dose of TGF- $\alpha$ was doubled and compared with an equivalent dose of EGF. With that dose, epithelial cell labelling indices in the oesophagus as well as in the fundic and antral mucosae did not differ between the three groups (Fig 2). In the duodenal mucosa, labelling indices were also not significantly different between the groups; however, they were increased by $13 \%$ in the EGF treated group compared with controls, $(\mathrm{p}<0 \cdot 10)$. In the jejunal mucosa, the $20 \mu \mathrm{g} / \mathrm{kg}$ dose of EGF increased labelling indices by $17 \%$ compared with controls, $(p<0.02)$ and by $15.5 \%$ compared with the TGF- $\alpha$ treated group, $(p<0.05)$. No effect was noted with TGF- $\alpha$. In the colonic mucosa, both rat EGF and rat TGF- $\alpha$ stimulated epithelial cell labelling indices, by $43 \%$ and $51 \%$, respectively, ( $<<0.001$; Fig 2$)$. In the pancreas, EGF did not affect acinar cell DNA synthesis; TGF- $\alpha$ increased this variable by $11 \%$ compared with controls but this increase did not reach significance $(p<0 \cdot 10)$. However, for the pancreas, labelling indices were significantly higher in the TFG- $\alpha$ treated group than in the EGF treated group $(16 \%, \mathrm{p}<0.02 ;$ Fig 2$)$.

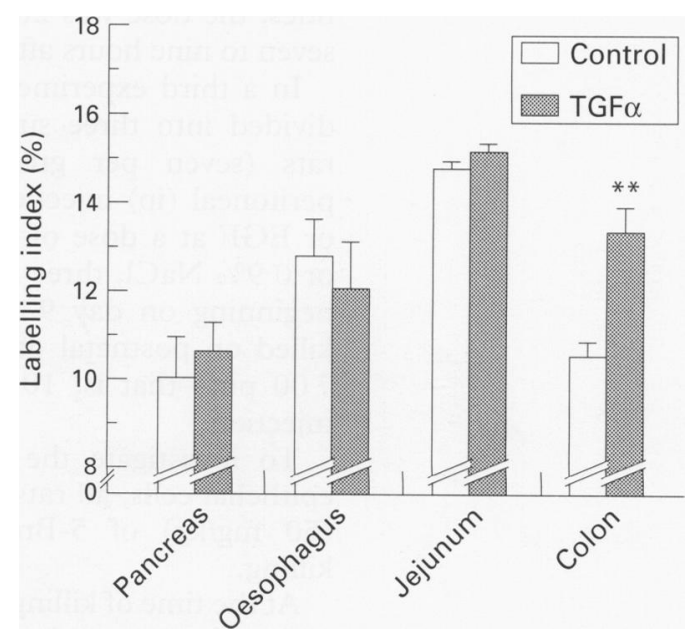

Figure 1: Effect of a five day subcutaneous treatment with either rat $\mathrm{TGF}-\alpha(10 \mu \mathrm{g} / \mathrm{kg})$ or $\mathrm{NaCl}$ (three times daily) on epithelial cell proliferation in exocrine pancreas and oesophageal, jejunal, and colonic mucosae. Rats were killed seven to nine hours after the last injection $\left({ }^{\star *} p<0.01\right)$. 


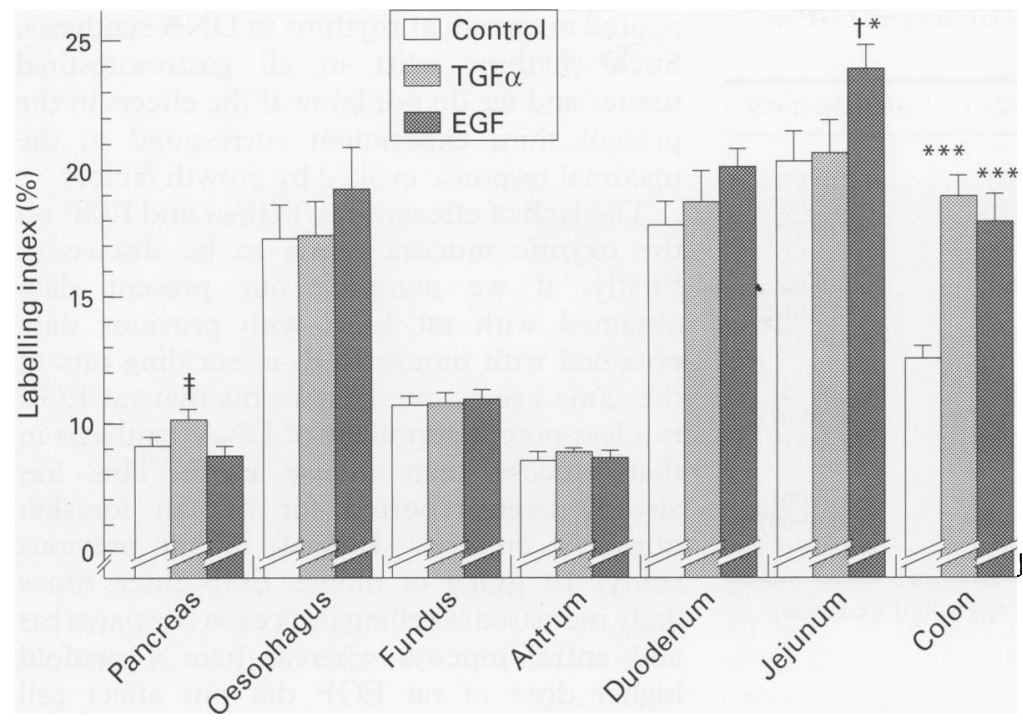

Figure 2: Effect of a five day subcutaneous administration of either rat $T G F-\alpha(20 \mu \mathrm{g} / \mathrm{kg})$, rat EGF $(20 \mu \mathrm{g} / \mathrm{kg})$, or $\mathrm{NaCl}$ (three times daily) on epithelial cell proliferation in the exocrine pancreas, oesophageal, fundic, antral, duodenal, jejunal, and colonic mucosae. Rats were killed seven to nine hours after the last injection. $¥ p<0.02 \mathrm{v} E G F$ treated group (and $p<0.10 \mathrm{v}$ control group, NS); $\neq p<0.05 \mathrm{v}$ TGF- $\alpha$ treated group; ${ }^{\star} p<0.02$ and $\star \star \star p<0.001 \mathrm{v}$ control group.

Because in the second study, cell proliferation was only weakly affected by both peptides in most digestive tissues, in the third experiment, three modifications were introduced: the dose was augmented to $100 \mu \mathrm{g} / \mathrm{kg}$, the route of administration was changed as it had been recently reported that ip administration was more efficient than $\mathrm{sc}$ in showing a trophic effect of EGF, ${ }^{21}$ and the time lapse between the last injection and the removal of tissues was prolonged to allow a potential stimulating effect to be more evident. ${ }^{19} 2034$ Under these experimental conditions, EGF stimulated labelling indices in the oesophagus by $40 \%(\mathrm{p}<0.05)$; TGF- $\alpha$ stimulated the same variable by $22.5 \%$ but this was not significant

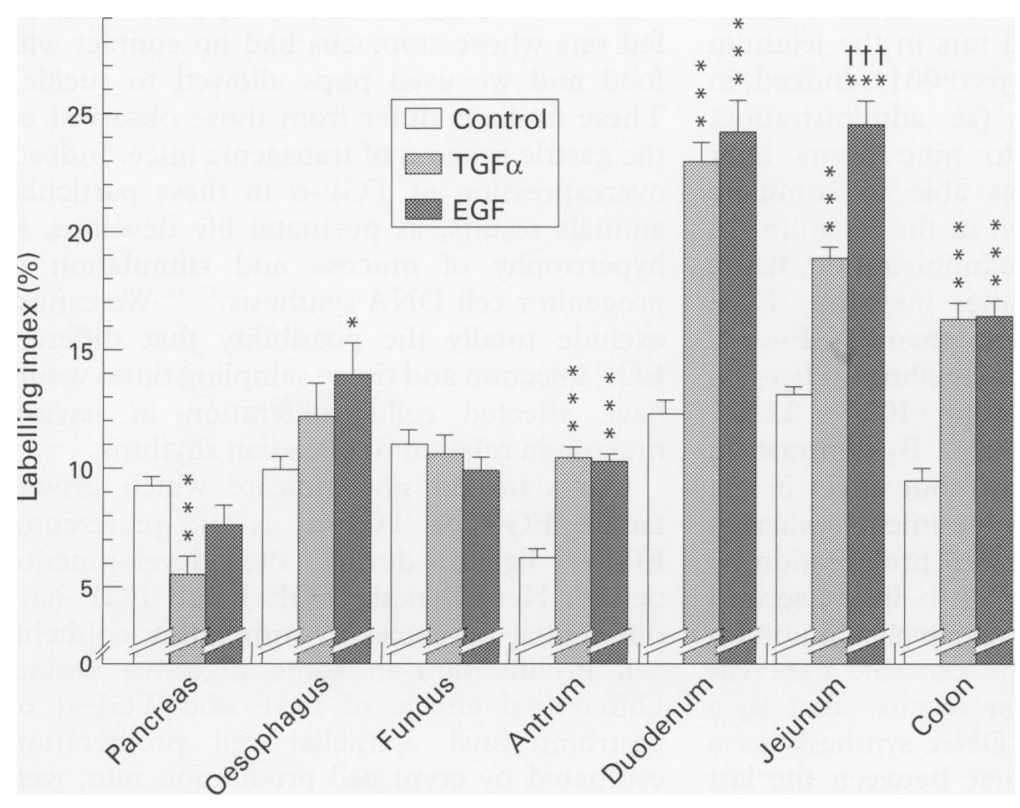

Figure 3: Effect of two day intraperitoneal administration of either rat TGF- $\alpha$ or EGF (100 $\mathrm{\mu g} / \mathrm{kg}$ ) or $\mathrm{NaCl}$ (three times daily) on epithelial cell proliferation in exocrine pancreas, oesophageal, fundic, antral, duodenal, jejunal, and colonic mucosae. Rats were killed $10-12$ hours after the last injection. ${ }^{*} p<0.05 ;{ }^{\star *} p<0.001 \mathrm{v}$ control group; $+t<p 0.001 \mathrm{v}$ $T G F-\alpha$ treated group.
(Fig 3). Again, no effect was noted on labelling indices in the fundic mucosa with either EGF or TGF- $\alpha$. By contrast, both EGF and TGF- $\alpha$ stimulated epithelial cell labelling indices in the antral mucosa with the same magnitude $(66 \%$ and $68 \%$ respectively, $p<0.001$; Fig 3 ). In the duodenal mucosa also, labelling indices were increased above controls by EGF (97\%) and by TGF- $\alpha(87 \%)$ (both $p<0.001)$. In the jejunal mucosa, EGF and TGF- $\alpha$ significantly increased labelling indices compared with controls, $(p<0.001)$, but EGF $(88 \%)$ was more potent than TGF- $\alpha(44 \%)$. The difference in labelling indices between EGF and TGF- $\alpha$ treated pups was also highly significant for the jejunal mucosa $(p<0.001)$. In the colonic mucosa, both growth factors similarly stimulated labelling indices by $75 \%(\mathrm{p}<0.001$; Fig 3 ). In the pancreas, again as in the second experiment, EGF had no significant effect on acinar cell DNA synthesis. By contrast, TGF- $\alpha$ significantly decreased pancreatic cell labelling indices by $40 \%$ compared with controls $(\mathrm{p}<0.001)$. It decreased the same variable by $27 \%$ compared with EGF but this was not significant $(p<0 \cdot 10$; Fig 3$)$.

In the third experiment, in which growth factor treatment was for only two days, increases in labelling indices were not accompanied by an increase in length of antral glands or intestinal crypts, expressed as number of cells per crypt column (Table II).

\section{Discussion}

Our present study provides the first information about the in vivo effect of exogenous TGF- $\alpha$ on epithelial cell proliferation in all types of digestive mucosae and the pancreas of suckling rats. Furthermore, it was the first time that relevant growth factors for the rat (rat EGF and TGF- $\alpha$ ) were used in this type of investigation.

A short period of treatment with these two growth factors (only two days) at the highest dose $(100 \mu \mathrm{g} / \mathrm{kg})$ was sufficient to significantly increase stomach and intestine weights of suckling rats compared with controls. This was in agreement with the stimulating effect on epithelial cell proliferation in rats treated with EGF and TGF- $\alpha$. Mean stomach weight, however, increased less than that of the intestines and did not vary significantly in the TGF- $\alpha$ treated group when it was expressed per animal body weight. In fact, only antral cell proliferation was stimulated by growth factors. In addition, only EGF significantly stimulated cell proliferation in the oesophagus, suggesting a likely identical stimulation in the forestomach. These data were consistent with the lesser increase in stomach weight in TGF- $\alpha$ treated rats.

The magnitude of tissue response to growth factors depended on the dose of growth factor given and varied according to tissues; colonic mucosa was the most sensitive and fundic mucosa the least. Moreover, some tissues displayed preferential sensitivity for one or other growth factor. Thus roughly equimolar doses of rat EGF and TGF- $\alpha$ (3.7 and 3.5 
TABLE II Effect of two day intraperitoneal administration of rat $T G F-\alpha$ or rat EGF on proliferative variables in antrum and intestine of suckling rats

\begin{tabular}{|c|c|c|c|}
\hline Variables & Controls $(n=7)$ & $E G F(n=7)$ & $T G F-\alpha(n=7)$ \\
\hline $\begin{array}{l}\text { Antrum: } \\
\text { No of cells/crypt column } \\
\text { No of labelled cells/crypt column } \\
\text { Labelling index }\end{array}$ & $\begin{array}{c}14 \cdot 4(0.06) \\
0 \cdot 88(0.06) \\
6 \cdot 2(0.4)\end{array}$ & $\begin{array}{l}14.3(0.04) \\
1.46(0.04)^{\star} \\
10.3(0.3)^{\star}\end{array}$ & $\begin{array}{c}14.2(0.05) \\
1.47(0.06)^{\star} \\
10.4(0.5)^{\star}\end{array}$ \\
\hline $\begin{array}{l}\text { Duodenum: } \\
\text { No of cells/crypt column } \\
\text { No of labelled cells/crypt column } \\
\text { Labelling index }\end{array}$ & $\begin{array}{c}15 \cdot 2(0 \cdot 15) \\
1.86(0 \cdot 08) \\
12 \cdot 3(0 \cdot 6)\end{array}$ & $\begin{array}{l}15.0(0.12) \\
3.63(0 \cdot 20)^{\star} \\
24.2(1 \cdot 3)^{\star}\end{array}$ & $\begin{array}{c}14.9(0.09) \\
3.42(0.12)^{\star} \\
22.9(0.7)^{\star}\end{array}$ \\
\hline $\begin{array}{l}\text { Jejunum: } \\
\text { No of cells/crypt column } \\
\text { No of labelled cells/crypt column } \\
\text { Labelling index }\end{array}$ & $\begin{array}{c}14.5(0 \cdot 10) \\
1.87(0.05) \\
13.0(0.3)\end{array}$ & $\begin{array}{l}14.5(0 \cdot 10) \\
3.52(0 \cdot 16)^{\star} \dagger \\
24.5(1 \cdot 0)^{\star} \ddagger\end{array}$ & $\begin{array}{l}14.4(0.05) \\
2.68(0.07)^{\star} \\
18.7(0.5)^{\star}\end{array}$ \\
\hline $\begin{array}{l}\text { Colon: } \\
\text { No of cells/crypt column } \\
\text { No of labelled cells/crypt column } \\
\text { Labelling index }\end{array}$ & $\begin{array}{c}14.2(0.24) \\
1.33(0.08) \\
9.3(0.6)\end{array}$ & $\begin{array}{c}14.0(0.07) \\
2.28(0.08)^{\star} \\
16.3(0.6)^{\star}\end{array}$ & $\begin{array}{c}14.2(0.06) \\
2.30(0.09)^{\star} \\
16.2(0.7)^{\star}\end{array}$ \\
\hline
\end{tabular}

Values are means (SEM). Parameters were estimated on coded slides. ${ }^{\star} \mathrm{p}<0.0001 v$ controls; $\nmid \mathrm{p}<0.001 ; \neq \mathrm{p}<0.0002 v$ TGF $-\alpha$ treated rats. $\mathrm{nmol} / \mathrm{kg}$ respectively, corresponding to 20 $\mu \mathrm{g} / \mathrm{kg}$ and 18.6 and $17.8 \mathrm{nmol} / \mathrm{kg}$, corresponding to $100 \mu \mathrm{g} / \mathrm{kg}$ ) had similar stimulating effects on colonic epithelial cell proliferation in the second experiment, and on antral, duodenal, and colonic epithelial cell proliferation in the third experiment. In addition, when given by the same (sc) route, rat $\mathrm{TGF}-\alpha$ increased labelling indices in colonic mucosa in a dose dependent manner, $(27 \%$ with the 10 $\mu \mathrm{g} / \mathrm{kg}$ dose and $51 \%$ with the $20 \mu \mathrm{g} / \mathrm{kg}$ dose in the first and second experiments respectively). The high response of colonic mucosa to EGF has also been emphasised by others ${ }^{23}$ indicating a specific sensitivity of this tissue to this growth factor family. This may explain the autocrine growth stimulation by $\mathrm{TGF}-\alpha$ in colonic cancers. $^{89}{ }^{11}$ By contrast, rat EGF and TGF- $\alpha$ showed differential activities in other tissues, whatever the route of administration and the time lapse between the last injection of growth factor and tissue removal-that is, EGF was more active in the oesophagus and jejunum and TGF- $\alpha$ was more active in the exocrine pancreas, with significant differences between TGF- $\alpha$ and EGF treated rats in the jejunum and pancreas $(p<0.02$ to $p<0.001)$. Indeed, in the second experiment (sc administration, tissue sampling seven to nine hours after injection) only EGF was able to stimulate epithelial cell proliferation in the jejunum. In the third experiment (ip administration, tissue sampling 10-12 hours after injection) EGF was twofold more potent than TGF- $\alpha$ in stimulating epithelial cell labelling indices in the oesophagus and jejunum $(40 \% v 22.5 \%$ and $88 \% v 44 \%$ respectively). By contrast, in the pancreas, EGF was without effect in the second and the third experiments whereas TGF- $\alpha$ stimulated acinar cell proliferation by $+11 \%$ and inhibited it by $-40 \%$ in the second and third experiments respecitvely. Inhibition of cell proliferation in the exocrine pancreas was surprising but similar results-that is, a decrease or increase in DNA synthesis as a function of the time course between the last injection and organ sampling-had already been reported by Scheving et al in mouse pancreas with mouse $\mathrm{EGF}^{19}{ }^{20}$ and by Potten et al in mouse ileal mucosa with mouse TGF- $\alpha{ }^{34}$ These apparent discrepancies seem to be related to circadian rhythms in DNA synthesis. Such rhythms exist in all gastrointestinal tissues and we do not know if the effects in the present third experiment correspond to the maximal response evoked by growth factors.

The lack of effect of rat TGF- $\alpha$ and EGF on the oxyntic mucosa needs to be discussed. Firstly, if we compare our present data obtained with rat EGF with previous data obtained with mouse EGF in suckling rats of the same age as ours, ${ }^{26}$ it seems that rat EGF is a less potent stimulant of DNA synthesis in that mucosa than mouse EGF. This has already been reported for human foreskin fibroblast culture. ${ }^{35}$ Indeed, in our previous study, $10 \mu \mathrm{g} / \mathrm{kg}$ of mouse EGF three times daily increased labelling indices in the pancreas and antral mucosa whereas here a twofold higher dose of rat EGF did not affect cell proliferation in the same tissues. A larger dose of mouse EGF $(100 \mu \mathrm{g} / \mathrm{kg}$ three times daily) stimulated cell proliferation in the fundic mucosa ${ }^{26}$ whereas in the present work, fundic mucosa remained unresponsive to an equivalent dose of rat EGF. Nevertheless, Arsenault and Ménard, who used a very high dose of mouse EGF ( $4 \mathrm{~g} / \mathrm{kg} /$ day) in suckling mice, reported no effect of EGF on DNA synthesis in the oesophagus ${ }^{23}$ whereas we found an effect with a lower dose of rat EGF $(300 \mu \mathrm{g} / \mathrm{kg} /$ day $)$ in suckling rats. These data all emphasise evident interspecies differences for both tissue responses to EGF and potencies of EGF of different origins. In any case, investigating the effect of its own growth factor in a species seems to be a more physiological procedure. Secondly, a lack of response of fundic mucosa to EGF and TGF- $\alpha$ was also indicated in the preliminary work of Goodlad et al who treated rats for three days with isomolar amounts of the two growth factors (species origin not given). ${ }^{15}$ Results were similar to ours although experimental conditions were different (they used parenterally fed rats whose stomachs had no contact with food and we used pups allowed to suckle). These findings differ from those observed on the gastric mucosa of transgenic mice. Indeed, overexpression of TGF- $\alpha$ in these particular animals results, as postnatal life develops, in hypertrophy of mucosa and stimulation of progenitor cell DNA synthesis. ${ }^{17}{ }^{18}$ We cannot exclude totally the possibility that different EGF injection and tissue sampling times would have affected cell proliferation in oxyntic mucosa in relation to circadian rhythms.

Our data do not indicate which growth factor, EGF or TGF- $\alpha$, is the preferential EGF-r ligand during the developmental period. Nevertheless, TGF- $\alpha$ and EGF have differential potencies in stimulating epithelial cell proliferation in some digestive tissues. Differential effects of EGF and TGF- $\alpha$ on gastrointestinal epithelial cell proliferation, estimated by crypt cell production rate, were also found by other authors, TGF- $\alpha$ exerting a less trophic effect than EGF, as increases, only found in mucosae from the small and large intestine, were never significant. ${ }^{15}$ Some quantitative differences in function have also 
been described in certain non-gastrointestinal tissues. Thus TGF- $\alpha$ was more potent than $\mathrm{EGF}$ in promoting angiogenesis ${ }^{36}$ and calcium release from fetal long bone in vitro, ${ }^{37}$ in inducing cell membrane ruffling, ${ }^{38}$ and in stimulating arterial blood flow in dogs. ${ }^{39}$ These dissimilarities may be explained by different intracellular routing and degradation of TGF$\propto / E G F-r$ and EGF/EGF-r complexes in certain tissues, perhaps because of the variation in the isoelectric point of the two proteins. ${ }^{40}{ }^{41}$ It has also been suggested that the two peptides bind differently to the EGF-r, an antibody raised against EGF-r being able to block TGF$\alpha$ binding to the receptor whereas it did not affect the EGF binding to that receptor. It was proposed that this antibody either stabilises a conformation of EGF-r not favourable for TGF- $\alpha$ binding or blocks a part of the receptor necessary for TGF- $\alpha$ binding but not EGF binding. ${ }^{42}$

To our knowledge, only two other studies have so far investigated the in vivo exogenous effect of TGF- $\alpha$ on cell proliferation in some digestive tissues. Thus it was reported that TGF- $\alpha$ stimulated the growth of pancreatic cancer transplanted in hamster cheek pouches. ${ }^{43}$ Very recently, Potten et al have shown that $\mathrm{TGF}-\alpha$ exerts some stimulatory effects on ileal mucosa of adult irradiated mice although little stimulation, no effect, or even some inhibition was also found depending on the administration schedule. ${ }^{34}$

In conclusion, we have shown that exogenous rat $\mathrm{TGF}-\alpha$ is able to increase digestive organ weights and to stimulate the in vivo proliferation of epithelial cells in most digestive tissues in suckling rats. Under our conditions, the colonic mucosa seemed very sensitive to EGF and TGF- $\alpha$ whereas fundic mucosa seemed unresponsive in vivo to the doses chosen. The two growth factors exerted similar activities in antral, duodenal, and colonic mucosae, but EGF was more potent than $T G F-\alpha$ in oesophageal and jejunal mucosae whereas TGF- $\alpha$ was more potent than EGF in the exocrine pancreas.

This study was supported by the Institut de la Santé et de la Recherche Médicale, INSERM We thank Ms Valérie Lebraud and Léone Grès for their helpful technical assitance.

1 Beauchamp RD, Barnard JA, McCutchen CM, Cherner JA Coffey RJ. Localisation of transforming growth factor $\alpha$ and its receptor in gastric mucosal cells: implication for a regulatory role in acid secretion and mucosal renewal. $\mathcal{F}$ Clin Invest 1989; 84: 1017-23.

2 Guglietta A, Lesch CA, Romano M, McClure RW, Coffey RJ. Effect of transforming growth factor- $\alpha$ on gastric acid RJ. Effect of transforming growth factor- $\alpha$ on gastric acid
secretion in rats and monkeys. Dig Dis Sci 1994; 39: secretion

3 Goldenring JR, Tsunnoda Y, Stoch SA, Coffey RJ, Modlin IM. Transforming growth factor-alpha (TGF $\alpha$ ) inhibition of parietal cell secretion: structural requirements for activity. Regul Pept 1993; 43: 37-47.

4 Rhodes JA, Tam JP, Finke M, Saunders J, Bernanke J, Silen $\mathrm{W}$, et al. Transforming growth factor $\alpha$ inhibits secretio of gastric acid. Proc Natl Acad Sci USA 1986; 83 3844-6.

5 Konturek SJ, Brzozowski T, Maka J, Dembinski A Slomiany A, Slomiany BL. Transforming growth facto alpha and epidermal growth factor in protection and healing of gastric mucosal injury. Scand $\mathcal{f}$ Gastroenterol 1992; 27: 649-55.

6 Polk jr WP, Dempsey PJ, Russell WE, Brown PI, Beauchamp RD, Barnard JA, et al. Increased production of transforming growth factor $\alpha$ following acute gastric injury. Gastroenteroly 1992; 102: 1467-74.

7 Romano M, Polk WP, Awad JA, Arteaga CL, Nanney LB,
Wargovich MJ, et al. Transforming growth factor $\alpha$ protection against drug-induced injury to the rat gastric mucosa in vivo. 7 Clin Invest 1992; 90: 2409-21.

8 Karnes jr WE, Wash JH, Wu SV, Kim RS, Martin MG Wong HC, et al. Autonomous proliferation of colon cancer cells that coexpress transforming growth factor $\alpha$ and its receptor. Gastroenterology 1992; 102: 474-85.

9 Markowitz SD, Molkentin K, Gerbic C, Jackson J, Stellato $\mathrm{T}$, Willson JKV. Growth stimulation by coexpression of transforming growth factor- $\alpha$ and epidermal growth factor-receptor in normal and adenomatous human colon epithelium. $\mathcal{F}$ Clin Invest 1990; 86: 356-62.

10 Yoshida K, Kyo E, Tsuda T, Tsuijino T, Ito M, Niimoto $M$ et $a l$. EGF and TGF- $\alpha$, the ligands of hyperproduced EGFR in human esophageal carcinomas cells, act as autocrine growth factors. Int $f$ Cancer 1990; 45: 131-5.

11 Ziober BL, Wilson JKV, Hymphrey LE, Childress-Fields K, Brattain MG. Autocrine transforming growth factor- $\alpha$ is Brattain MG. Autocrine transforming growth factor- $\alpha$ is
associated with progression of transformed properties in
human colon cancer cell. $₹$ Biol Chem 1993; 268:691-8.

12 Chen MC, Lee AT, Soll AH. Mitogenic response of canine fundic epithelial cells in short-term culture to transforming growth factor $\alpha$ and insulinlike growth factor I. 7 Clin Invest $1991 ; 87$ : 1716-23.

13 Chen MC, Lee AT, Karnes WE, Avedian D, Martin M Sorvillo JM, et al. Paracrine control of gastric epithelial cell growth in culture by transforming growth factor- $\alpha$. Am f Physiol 1993; 264: G390-6.

14 Rutten MJ, Dempsey PJ, Solomon TE, Coffey jr RJ. TGF- $\alpha$ is a potent mitogen for primary cultures of guinea pig is a potent mitogen for primary cultures of guinea pig gastric muc

15 Goodlad RA, Lee CY, Ghatei MA, Bloom SR, Wright NA. Differential effects of epidermal growth factor and transforming growth factor- $\alpha$ on gastrointestinal epithelial cell proliferation. Proc Nutr Soc 1993; 52: 185A.

16 Sandgren EP, Luetteke NC, Palmiter RD, Brinster RA, Lee DC. Overexpression of TGF $\alpha$ in transgenic mice: Induction of epithelial hyperplasia, pancreatic metaplasia, and carcinoma of the breast. Cell 1990; 61: 1121-35.

17 Dempsey PJ, Goldenring JR, Soroka CJ, Modlin IM, McClure RW, Lind CD, et al. Possible role of transforming growth factor $\alpha$ in the pathogenesis of Ménétrier's disease: supportive evidence from humans and transgenic mice. Gastroenterology 1992; 103: and transge $1950-63$.

18 Sharp R, Babyatsky MW, Takagi H, Tagerud S, Wang TC, Bockman DE, et al. Transforming growth factor a disrupts the normal program differentiation in the gastric mucosa of transgenic mice. Development 1995; 121: 149-61.

19 Scheving LE. The circadian influence of epidermal growth factor, insulin and glucagon on cell proliferation in digestive tract in: Chronobiology and Digestive System. Cincinnati: US Department of Health and Human Services, 1984: 41-68. (NIH publ No S4-857).

20 Scheving LA, Tsai TH, Scheving LE, Hoke WS. Effect of epidermal growth factor (EGF) on $\left({ }^{3} \mathrm{H}\right) \mathrm{TdR}$ incorporation into DNA in ad lib fed and fasted CD2F 1 mice. poration into DNA in ad

21 Bamba T, Tsujikawa T, Hosoda S. Effect of epidermal growth factor by different routes of administration on the mall intestinal mucosa of rats fed elemental diet. Gastroenterol fpn 1993; 28: 511-7.

22 Dembinski AB, Johnson LR. Effect of epidermal growth factor on the development of rat gastric mucosa. Endocrinology 1985; 116: 90-4.

23 Arsenault P, Ménard D. Stimulatory effects of epidermal growth factor on deoxyribonucleic acid synthesis in the gastrointestinal tract of the suckling mouse. Comp gastrointestinal tract of the suckling mouse. Comp
Biochem Physiol B Biochem Mol Biol 1987; 86: 123-7.

24 O'Loughlin EV, Chung M, Hollenberg M, Hayden J, Zahavi I, Gall DG. Effect of epidermal growth factor on Zahavi I, Gall DG. Effect of epidermal growth factor on 249: G674-8

25 Pollack PF, Goda T, Colony PC, Edmonds J, Thornburg $\mathrm{W}$, Korc $M$, et al. Effects on enterally fed epiderma growth factor on the small and large intestine of the suckling rat. Regul Pept 1987; 17: 121-32.

26 Puccio F, Lehy T. Oral administration of epidermal growth factor in suckling rats stimulates cell DNA synthesis in fundic and antral gastric mucosae as well as in intestinal mucosa and pancreas. Regul Pept 1988; 20: 53-64.

27 Hormi K, Lehy T. Developmental expression of transforming growth factor- $\alpha$ and epidermal growth factor recming growth factor- $\alpha$ and epidermal growth factor receptor proteins in the human pancreas

28 Hormi K, Onolfo JP, Gres L, Lebraud V, Lehy T Developmental expression of transforming growth factor$\alpha$ in the upper digestive tract and pancreas of the rat. Regul Pept 1995; 55: 67-77.

29 Pérez-Tomas R, Culleré X, Diaz C. Immunohistochemical localization of transforming growth factor $\alpha$ in the developing rat colon. Gastroenterology 1993; 104: 789-95.

30 Raaberg L, Nexo E, Mikkelson JD, Poulsen SS Immunohistochemical localisation and developmenta aspects of epidermal growth factor in the rat. Histochemistry 1988; 89: 351-6.

31 Toyoda S, Lee PC, Lebenthal E. Interaction of epiderma rowth factor with specific binding sites of enterocytes isolated from rat small intestine during development. Biochim Biophys Acta 1986; 886: 295-301.

32 Puccio F, Lehy T. Bombesin ingestion stimulates epithelia digestive cell proliferation in suckling rats. Am $\mathcal{F}$ Physiol 1989; 256: G328-34. 
33 Alvares EP. The effect of fasting on cell proliferation in the gastric mucosa on the 14-day old suckling rat. Brazilian $\mathfrak{f}$ Med Biol Res 1992; 25: 641-9.

34 Potten CS, Owen G, Hewitt D, Chadwick CA, Hendry H, Lord BI, et al. Stimulation and inhibition of proliferation in the small intestinal crypts of the in the small intestinal crypts of the mouse after in vivo

35 Schaudies RP, Savage jr CR. Isolation of rat epiderma Schaudies RP, Savage jr CR. Isolation of rat epidermal
growth factor (r-EGF): chemical, biological and growth factor (r-EGF): chemical, biological and
immunological comparisons with mouse and human EGF. Comp Biochem Physiol 1986; 84: 497-505.

36 Schreiber AB, Winkler ME, Derynck R. Transforming growth factor- $\alpha$ : a more potent angiogenic mediator than epidermal growth factor. Science 1986; 232: 1250-3.

37 Stern HP, Krieger NS, Nissenson RA, Williams RD, Winkler ME, Derynck R, et al. Human transforming growth factor-alpha stimulates bone resorption in vitro. $f$ Clin Invest 1985; 76: 2016-9.

38 Mydral SE, Twardzik DR, Auersperg N. Cell-mediated coaction of transforming growth factors; Incubation of type $\beta$ with normal rat kidney cell produces a soluble activity that prolongs the ruffling response to type $\alpha . \mathcal{F}$ Cell Biol 1986; 102: 1230-4.

39 Gan BS, Hollenberg MD, MacCannell $\mathrm{KL}$, Ledris $\mathrm{K}$, Winkler ME, Derynck R. Distinct vascular actions of epidermal growth factor-urogastrone and transforming growth factor- $\alpha$. F Pharmacol Exp Ther 1987; 242: 331-7.

40 Decker SJ. Epidermal growth factor and transforming Decker SJ. Epidermal growth factor and transforming
growth factor- $\alpha$ induce differential processing of the epidermal growth factor receptor. Biochem Biophys Res Commun 1990; 166: 615-21.

41 Ebner SJ, Derynck R. Epidermal growth factor and transforming growth factor- $\alpha$ : differential intracellular routing and processing of ligand-receptor complexes. Cell Regul 1991; 2: 599-612.

42 Winkler ME, O'Connor L, Winget M, Fendly B. Epidermal growth factor and transforming growth factor $\alpha$ bind differently to epidermal growth factor receptor. Biochemistry 1989; 28: 6373-8.

43 Davies N, Kapur P, Gillespie J, Guillou PJ, Poston GJ. Transforming growth factor $\alpha$ is trophic to pancreatic Transforming growth factor $\alpha$ is troph
cancer in vivo. Gut 1993; 34: 1097-8. 